\title{
PENERAPAN GOOD CORPORATE GOVERNANCE (GCG) PADA NON GOVERMENTAL ORGANIZATIONS (NGO)
}

\author{
Studi kasus: Migrant Institutee \\ Mawarto \\ Sekolah Tinggi Ilmu Ekonomi Dharma Bumiputera \\ E-mail:mawarto@yahoo.com
}

\begin{abstract}
ABSTRAK:
Setiap Organisasi yang berorientasi laba maupun non laba dituntut dapat menerapkan Tata Kelola Perusahaan sebagai bentuk akuntabilitas organisasi terhadap para pemangku kepentingan, Penerapan prinsip akuntabilitas dalam Lembaga Swadaya Masyarakat (LSM) menjadi penting karena, LSM adalah lembaga yang bekerja untuk masyarakat dan berdasarkan pada kepercayaan. Secara konsep Tata Kelola Perusahaan meliputi aspek keterbukaan, akuntabilitas, pertanggungjawaban, kemandirian dan kesetaraan namun dalam penelitian ini dibatasi pada aspek akuntabilitas. Hasil penelitian menunjukan bahwa Migrant Institutetelah melaksanakan akuntabilitas sebagai Lembaga Swadaya Masyarakat dengan indikator memiliki struktur organisasi, pembagian tugas pada tingkatan manajemen, persyaratan dan masa jabatan, proses pengambilan keputusan serta dokumentasi notulen rapat, Direktur Eksekutif dan Anggota Eksekutif tidak boleh merangkap jabatan sebagai Aparatur Sipil Negara (ASN). Hal lain yang diperlukan Organ Pendukung pelaksanaan tata kelola perusahaan, seperti Internal Auditor, komite kebijakan resiko.
\end{abstract}

Kata Kunci:

Kajian penerapan, $G C G$, Akuntabilitas, $N G O$,

\section{ABSTRACT:}

Any profit-oriented and non-profit oriented organization is required to implement Corporate Governance as a form of organizational accountability to all stakeholders. Implementation of accountability principles in NonGovernmental Organizations (NGOs) is important because, NGOs are institutions that work for the community and based on trust. The concept of Corporate Governance includes aspects of openness, accountability, responsibility, independence and equity, but in this study is limited to aspects of accountability. The results of the research show that Migrant Institutehas implemented accountability as Non-Governmental Organization with indicators of organizational structure, division of tasks at management level, requirements and tenure, decision process and documentation of meeting minutes, Executive Director and Executive Member may not concurrently serve as Civil Apparatus State (CAS). Other things that are needed by the Supporting Organizations of corporate governance, such as the Internal Auditor, the risk policy committee.

Keyword:

Implementation review, GCG, Accountability, $N G O$, 


\section{PENDAHULUAN}

Good Corporate Governance (GCG) adalah suatu konsep yang tidak asing lagi bagi masyarakat Indonesia. Konsep GCG diperkenalkan pertama kali pada tahun 1998 ketika terdapat usulan penyempurnaan peraturan pencatatan Bursa Efek Indonesia. Mulai popular istilah Good Corporate Governance atau tata kelola perusahaan yang baik tidak dapat dilepaskan maraknya skandal perusahaan yang menimpa perusahaan perusahaan besar baik yang terjadi di Amerika maupun yang terjadi di Indonesia seperti beberapa Bank pemerintah dan swasta di likwidasi sebagai akibat praktek tata kelola perusahaan yang buruk ( Bad Corporate Governance ). Selain kebangkrutan dibeberapa korporasi hasil penelitian Indonesia Corruption Watch ( ICW) tahun 2007 - 2012 ( Viva.co.id Minggu, 15 September 2013 ) terdapat 120 kasus penyelewengan dana bansos total penyelewengan dana bansos di Indonesia berdasarkan hasil penyelidikan penegak hukum mencapai Rp 411 triliun, Dana yang semula ditujukan untuk masyarakat tidak mampu dalam bentuk uang atau barang pada implementasinya dibelokkan disalurkan ke Lembaga Swadaya Masyarakat (LSM) fiktif yang menerima dana itu atas nama masyarakat, setelah menerima dana bansos, distribusi dan rimbanya tidak jelas sedangkan pembentukan dana sosial dan peng-gunaannya adalah kewenangan pemerintah daerah, hal tersebut berdampak pada citra LSM rendah. Berdasarkan kondisi tersebut patut diduga bahwa tingkat governance-nya dalam prinsip akuntabilitas pemerintah daerah rendah dan tidak ada transparansi dan akuntabilitas dalam pengelolaan dana LSM yang bersumber dari pemerintah atau masyarakat.

Menurut National Committee on Governance dalam Sukrisno ( 2014 ) terdapat 5 prinsip GCG yaitu (a) Tranparansi artinya kewajiban bagi para pengelola untuk menjalankan prinsip keterbukaan dalam proses keputusan dan penyampaian informasi. (b) Akuntabilitas artinya prinsip bagi para pengelola berkewajiban untuk membina system akuntansi yang efektif untuk menghasilkan laporan keuangan yang dapat dipercaya, sehingga diperlukan kejelasan fungsi, pelaksanaan, dan pertanggungjawaban setiap organ perusahaan (c) Res-ponsibilitas artinya para pengelola wajib memberikan pertanggungjawaban atas semua tindakan dalam mngelola perusahaan (organisasi ) pada 
para pemangku kepentingan. (d) Independensi artinya para pengelola dalam mengambil keputusan harus bebas dari tekanan atau pengaruh dari pihak manapun, (e) Kesetaraan artinya para pengelola harus memperlakukan pemangku kepentingan primer (pemasok, pelanggan, karyawan dan pemerintah) dan pemangku kepentingan sekunder ( pemerintah dan masyarakat ) secara adil dan setara. Salah satu kunci untuk memenangkan persaingan global dan menjalankan organisasi bisnis secara berkelanjutan adalah dengan mengimplementasikan Good Corporate Governance (GCG). Kemampuan pulih dari krisis salah satunya didukung dari kemampuan berkompetisi secara global. Kaihatu (2006) menjelaskan bahwa kompetisi global yang terjadi antarnegara, dipengaruhi juga oleh kompetisi antarkorporat, sehingga pemulihan perekonomian satu negara bergantung pada kinerja korporat di masing-masing negara. Kondisi Indonesia yang sulit membaik di masa krisis disebabkan karena korporat kita belum dikelola secara benar atau belum menjalankan governansi. Survey dari Booz-Allen di Asia Timur pada tahun 1998 menunjukkan bahwa Indonesia memiliki indeks corporate governance paling rendah dengan skor 2,88 jauh di bawah Singapura $(8,93)$, Malaysia $(7,72)$ dan Thailand $(4,89)$ (Kaihatu, 2006). Munculnya berbagai skandal dan penyalahgunaan fungsi dari korporasi menjadi ukuran buruknya corporate governance sebuah korporasi, karena salah satu aspek yang menjadi acuan adalah terkait transparansi dan akuntabilitas korporasi (Fikri et al. 2010).

Disamping korporasi dibidang perekonomian, pemulihan krisis di Indonesia juga didukung oleh kontribusi Non Governmental Organization. Kemunculan NGO di Indonesia dimulai dengan berdirinya Lembaga Sosial Desa para tahun 50-an. Disusul dengan Perkumpulan Keluarga Berencana Indonesia pada tahun 1957. Sementara Pada tahun 60-an berdirilah Bina Desa dan Bina Swadaya. Sejak saat itu terus lahir berbagai NGO baru dengan momentum puncaknya adalah pasca runtuhnya rezim Orde baru (1966-1998). Salah satu peran penting dari keberadaan NGO di Indonesia adalah munculnya perubahan positif dari sisi kehidupan sosial masyarakat.

Permasalahan transparansi keuang-an dalam sebuah NGO menjadi faktor yang perlu diperhatikan. Sebagai contoh yaitu terkait kasus sumber dana pada NGO Greenpeace 


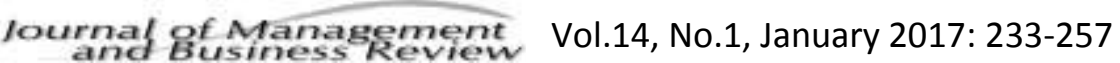

pada tahun 2011. Sehingga muncul berbagai regulasi yang menuntut perlunya mengontrol NGO dengan audit publik dan membuat peraturan setingkat Undang-Undang untuk mengatur NGO sebagai civil society. Hasil monitoring dan evaluasi terhadap sejumlah NGO khususnya pada aspek manajemen intern dan program intern menunjukan bahwa, umunya NGO masih sangat lemah dalam hal pengelolaan program. Beberapa indikatornya diantaranya, (1) lemahnya penanganan program secara sistematis mulai dari identifikasi masalah, pengumpulan data dan perencanaan program dengan konsep, pendekatan serta arah program. Kemudian (2) umumnya hanya merupakan proyek dan uji coba sehingga kurang melibatkan komunitas dan masyarakat yang menjadi objek program, kurang memperhatikan potensi lokal setempat dan kurang cepat merespon masalah-masalah yang menjadi kepedulian umum masyarakat. Selain itu (3) bersifat tertutup, performa kerja rendah dan sangat bergantung pada dana dari luar (Abidin dan Rukmini 2004).

Berbagai faktor dapat mempengaruhi dukungan masyarakat terhadap NGO. Diantaranya disebutkan bahwa masyarakat berpenghasilan Rp 750 ribu hingga Rp1,5 juta ke atas menolak menyumbang ke NGO karena tidak percaya dengan orang-orangnya (43\% dan $34 \%$ ), tidak punya uang (22\% dan $28 \%$ ), tidak percaya organisasinya ( $14 \%$ dan $11 \%)$, tidak percaya programnya $(11 \%$ dan 7\%), dan sisanya (10\%) karena faktor-faktor lain, seperti tidak ada follow up ketika terdapat permintaan. Sementara masyarakat berpenghasilan di bawah Rp750 ribu menyatakan menolak mendukung NGO, karena tidak punya uang (49\%), tidak percaya orangnya $(28 \%)$, tidak percaya programnya $(7 \%)$, tidak percaya organisasinya $(6 \%)$, dan sisanya (10\%) karena laktor- faktor lain (Abidin dan Rukmini 2004).

Data di atas menunjukkan bahwa faktor kepercayaan menjadi sangat penting dan harus dibangun oleh NGO untuk menarik dukungan masyarakat, terutama masyarakat kelas atas. Karena kelas masyarakat tersebut merupakan calon pendukung atau donatur potensial bagi NGO. Bagi masyarakat kelas menengah ke atas rendahnya dukungan terhadap NGO disebabkan karena ketidakpercayaan pada orang-orang NGO, program-program dan organisasinya. 
Minimnya tingkat kepercayaan masyarakat terhadap NGO terkait dengan rendahnya akuntabilitas dan transparansi NGO di mata publik yang berdampak pada menurunnya dukungan serta legitimasi sosial dan moral NGO tersebut di mata publik, misalnya tidak pernah melaporkan program dan keuangan yang dikelolanya secara transparan.

Dalam hal terjadi fraud di sektor pemerintah atau korporasi pada umumnya terletak pada kelemahan corporate governance, perusahan yang lemah governance-nya akan di hukum oleh para pelaku pasar modal berupa menurunnya harga saham perusahaan yang bersangkutan, (Tuanakotta, 2016 ). Kondisi demikian juga bisa terjadi pada Lembaga Swadaya Masyarakat, yang sumber pendanaanya berasal dari masyarakat oleh karena itu meminalisasi kemungkinan kelemahan yang terjadi, pada setiap pemimpin harus selalu berusaha melakukan perbaikan. Dalam perkembangan dewasa ini, ketika Direksi dan Manajemen mengembangkan Nilai, Kebijakan dan prinsip prinsip yang mendukung budaya perusahaan ( organisasi ) dan tindakan karyawan, pengawasan pemangku kepentingan, kebutuhan tranparansi dan akuntabilitas publik menjadi pertimbangan utama Dunn, Brooks ( 2012-45 ) untuk memberikan peningkatan pelayanan pada masyarakat terutama pada Lembaga Swadaya Masyarakat.

Penerapan prinsip Corporate Governance dalam konteks pelayanan, pemberdayaan maupun pembangunan publik, menjadi sesuatu prioritas dilakukan agar tercapai tata kelola NGO yang baik. Menurut Sutedi ( 2011 ) unsur unsur corporate governance yang diperlukan dari internal perusahaan organisasi adalah (a) keterbukaan dan kerahasiaan (b) tranparansi (c) accountability (d) fairness dan (e) aturan dari code of conduct. Undang-Undang RI No. 17 Tahun 2013 tentang Organisasi pasal 21 huruf e mengamanahkan bahwa Organisasi Kemasyarakatan memiliki kewajiban untuk melakukan pengelolaan 
keuangan secara transparan dan akuntabel, dalam hal ini LSM sebagai bagian dari organisasi kemasyarakatan juga memiliki kewajiban yang sama.

Berdasarkan beberapa uraian tersebut diatas penerapan prinsip akuntabilitas sangat penting bagi sebuah korporasi ataupun lembaga pemerintah dan lembaga swadaya masyarakat. Prinsip yang harus dipegang dalam akuntansi sektor publik menurut Mardiasmo (2011) adalah akuntabilitas, pengawasan, daya tanggap, profesioanalisme, efisiensi dan efektifitas, transparansi, wawasan kedepan, partisispasi, dan penegakan hukum. Pengertian Akuntabilitas menurut Mardiasmo (2011) diartikan sebagai bentuk kewajiban mempertanggungjawabkan keberhasilan atau kegagalan pelaksanaan visi misi organisasi yang telah ditetapkan sebelumnya, melalui suatu media pertanggungjawaban yang dilaksanakan secara periodik. Oleh karenanya diperlukan kajian mengenai penerapan prinsip akuntabilitas dalam GCG pada Organisasi Kemasyarakatan terutama LSM dengan tujuan untuk mengkonfirmasi Standar Pelaksanaan Akuntabilitas telah dilaksanakan oleh LSM dan juga untuk membandingkan hasil penelitian sebelumnya yang dilakukan oleh peneliti terdahulu.

Penelitian terkait akuntabilitas dan transparansi telah dilakukan sebelumnya Antara lain Hafidh (2008) menyatakan bahwa standar terkait pelaksanaan akuntabilitas bagi LSM belum cukup memadai dalam upaya pengungkapanya. Sedangkan menurut Putri (2013) Implementasi akuntabilitas dan transparansi yang telah diterapkan oleh rumah sakit Saiful Anwar Malang telah berjalan dengan baik. Sedangkan penelitian Gozyali (2012) menyatakan bahwa laporan keuangan dan pengelolaan kinerja Indonesia Corruption Watch (ICW) dinilai akuntabel Untuk mengetahui kondisi dan perkembangan pelaksanaan akuntabilitas bagi sebuah NGO perlu melakukan Evaluasi penerapan CGC pada NGO yang berorientasi pada peningkatan akuntabilitas dan transparansi untuk mengidentifikasi standar 
serta indikator penting yang harus dipenuhi NGO sehingga berdampak pada peningkatan performa kinerja organisasi, kepercayaan para shareholder/stakeholder serta mendongkrak citra positif NGO dimata publik.

\section{TUJUAN}

Kajian ini bertujuan untuk mengidentifikasi komponen dalam prinsip GCG dan menganalisis pelaksanaan akuntabilitas dan transparansi pada Migrant Institute sebagai langkah menerapkan prinsip Good Corporate Governance. Kajian ini bersifat explanatory reseach untuk dapat menunjukan gambaran penerapan prinsip-prinsip Good Corporate
Governance pada NGO.

\section{METODE RISET}

Obyek penelitian dilakukan pada Migrant Institute di Jakarta Timur melalui obsevasi, mengajukan pertanyaan pada pejabat yang berkompeten sesuai bidangnya, serta data sekunder berupa dokumen pendukung yang memperkuat jawaban pertanyaan. Ruang lingkup kajian ini adalah mengidentifikasi faktor kunci menurut standar Konsil LSM Indonesia (2014). Kerangka penelitian ditunjukan pada Gambar 1.

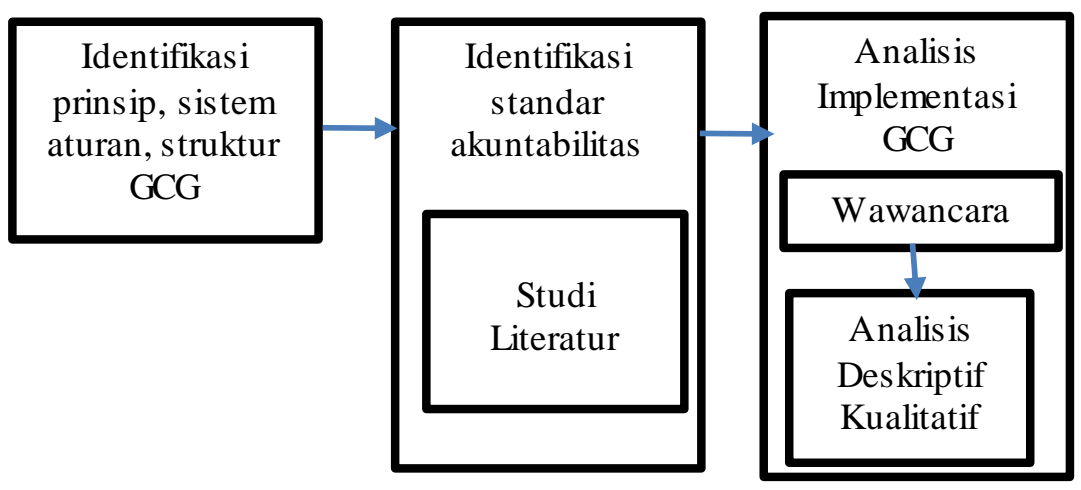

Gambar 1.

Kerangka kajian 
Metode yang digunakan adalah :

(1) Studi literatur

Kajian literatur dilakukan dengan mengumpulkan informasi ilmiah berupa teori-teori yang pernah berkembang terkait

Laporan keuangan, Anggaran Dasar,

Data Diri Pengurus, Notulen Rapat (dokumen tersebut hanya ditunjukan untuk dibaca ditempat dan tidak boleh digandakan )

(2) Wawancara

Wawancara dilakukan dengan mengadakan komunikasi dengan sumber data, yaitu bapak Adi Chandra Utama selaku Direktur Eksekutif untuk mendapatkan informasi yang terkait kebijakan strategis, sedangkan untuk mendapatkan dokumen pendukung yang relevan, wawancara dilakukan dengan bapak Agus Salim selaku Manager Program. Komunikasi tersebut dilakukan dengan dialog (Tanya jawab) secara lisan dan melalui telpon atau media sosial, untuk hal hal yang perlu penjelasan ulang atau klarifikasi.

(3) Analisis Deskriptif Kualitatif

Metode analisis yang digunakan merupakan analisis kualitatif (Alex 2014) menggunakan teori Bogdan dan Biklen
$G C G$ dan NGO. Kajian berfokus pada identifikasi komponen penyusun $G C G$ dan faktor penting yang dapat diadopsi dalam pengelolaan $N G O$. Serta melakukan telaah terhadap dokumen yang diberikan seperti sehingga diperoleh uraian tertulis tentang perilaku organisasi yang diamati dari sudut pandang yang utuh, komprehensif, dan holistik. Analisi Deskriptif Kualitatif dilakukan untuk menggambarkan fakta-fakta yang terjadi di Migrant Institute kemudian dilanjutkan dengan dengan upaya pengambilan keputusan umum berdasarkan fakta-fakta historis tersebut. Kajian deskriptif kualitatif dilakukan dengan menafsirkan dan menuturkan data yang bersangkutan dengan situasi yang sedang terjadi.

\section{PEMBAHASAN}

A. Sejarah NGO

Istilah "Non Governmental Organization" digunakan sejak berdirinya $\mathrm{PBB}$ pada tahun 1945, tepatnya pada pada Piagam PBB Pasal 71 Bab 10 tentang peranan konsultatif Non Governmental Organization. Awalnya istilah ini digunakan untuk membedakan antara hak partisipatif badan-badan pemerintah (Intergovernmental 
Agencies) dan organisasi-organisasi swasta international (International Private Organizations). Untuk itu sejak tahun 1970, NGO memperoleh status resmi (consultative status) didalam PBB. Sampai sekarang, hampir semua kesempatan dalam pertemuan PBB delegasi NGO berhak hadir dengan suara penuh/disediakan forum-forum khusus untuk NGO. Kehadiran NGO dalam sistem PBB ini telah pula dilembagakan secara permanen, di bawah UNDP, di sebut NGO Forum.

World Bank, mendefenisikan NGO sebagai "organisasi swasta yang menjalankan kegiatan untuk meringankan penderitaan, mengentaskan kemiskinan, memelihara lingkungan hidup, menyediakan layanan sosial dasar atau melakukan kegiatan pengembangan masyarakat". Dalam sebuah dokumen penting World Bank, Working With NGOs, disebutkan, "Dalam konteks yang lebih luas, istilah NGO dapat diartikan sebagai semua organisasi nirlaba (non-profit organization) yang tidak terkait dengan pemerintahan.

$$
N G O \text { pada umumnya adalah }
$$

organisasi berbasis nilai (value-based organizations) yang bergantung kepada, baik sebagian atau keseluruhan, bantuan amal (charitable donations) dan pelayanan sukarela (voluntary service).

Muhtar (2010) menjelaskan bahwa Korten pernah membagi perkembangan generasiNGO menjadi tiga yaitu:

1. Generasi pertama NGO, memiliki fokus lebih kepada distribusi bantuan secara langsung kepada yang membutuhkan. Contoh bantuan antara lain makanan dan pelayanan kesehatan.

2. NGO generasi kedua berorientasi kepada pembentukan pola pembangunan dengan skala lokal. Dalam tahap evolusi ini, NGO memfokuskan pada pemberdayaan komunitas lokal agar dapat memenuhi kebutuhannya sendiri.

3.NGO generasi ketiga, orientasi akan difokuskan untuk memajukan kebijakan dan institusi di level lokal, nasional, dan internasional. Pada tahap ini, NGO merubah perannya dari service providing menjadi katalis perubahan. Korten sendiri menyebut generasi ketiga ini sebagai sustainable systems development. Dengan demikian, NGO 
pada dasarnya mengalami perubahan dari relief NGO (distribusi bantuan) kepada development NGO (berorientasi pada pembangunan).

Secara umum dalam prakteknya NGO dapat dikategorikan, menjadi dua (Suharko 1998):

\section{NGO operasional}

NGO ini bertujuan untuk merancang dan mengimplementasikan program-program yang berorientasi pada pembangunan (development-related). Salah satu model NGO operasional yang menonjol adalah community-based organizations (CBO), yang "bertugas" kelompok masyarakat yang spesifik di suatu wilayah geografis. Misalnya, menjalankan program pemberdayaan masyarakat melalui kredit mikro di kecamatan atau desa tertentu. Salah satu contoh NGO operasional di Indonesia adalah Bina Swadaya.

\section{NGO advokasi}

Umumnya, NGO advokasi berusaha untuk mengangkat atau mempertahankan issuetertentu, biasanya dengan meningkatkan public awareness atau public acceptance terhadap suatu isu. Isu-isu tersebut misalnya seperti kesetaraan gender, pelestarian ling- kungan hidup, dan perlindungan Hak Asasi Manusia . Dalam bekerja, NGO advokasi umumnya menggunakan cara loby, pendekatan melalui media massa, atau pengerahan massa. Salah satu contoh NGO advokasi di Indonesia adalah Wahana Lingkungan Hidup Indonesia (WALHI).

Migrant Institutemerupakan jenis NGO yang melakukan fungsi keduanya selama 1 dekade terakhir. Hal ini ditunjukan dengan konsistensi dalam melakukan upayaupaya advokasi dan edukasi kepada Buruh Migran Indonesia (TKI) sejak pra-migrasi, migrasi maupun pendampingan serta pemberdayaan pasca pasca-migrasi dengan membentuk sebuah perkumpulan yang bernama Keluarga Migran Indonesia (KAMI). KAMI merupakan wadah bagi para purna- TKI untuk bergotong royong dan saling menguatkan terutama dalam sektor perekonomian sehingga mereka bisa mandiri dan memiliki keberdayaan dari sisi ekonomi di tanah air, sehingga para purnaTKI tidak perlu lagi kembali bekerja ke luar negeri.

B. Good Corporate Governance

Alex (2014) menjelaskan bahwa 
istilah Good Corporate Governance (GCG) atau corporate governance (CG) pertama kali diperkenalkan oleh Cadbury Committee tahun 1992 dalam laporannya yang dikenal sebagai Cadbury Report. Sejumlah Negara mempunyai definisi tersendiri tentang GCG. Beberapa Negara mendefinisikannya dengan pengertian yang agak mirip meskipun berbeda istilah. Hal ini terjadi karena GCG merupakan sebuah konsep sehingga tidak memiliki definisi tunggal. Berikut berbagai definisi GCG yang bisa peneliti sajikan.

1. Cadbury Committee: GCG adalah prinsip yang mengarahkan dan
mengendalikan perusahaan agar mencapai keseimbangan antara kekuatan serta kewenangan perusahaan dalam memberikan pertanggungjawabannya kepada para shareholder khususnya, dan stakeholder pada umumnya. Tentu saja hal ini dimaksudkan pengaturan kewenangan Direktur, Manajer, Pemagang Saham, dan pihak lain yang berhubungan dengan perkembangan perusahaan di lingkungan tertentu (Surya dan Yustiavandana 2006).

2. Center for European Policy Studies
(CEPS): GCG merupakan seluruh sistem yang dibentuk mulai dari hak (right), proses, serta pengendalian, baik yang ada didalam maupun diluar manajemen perusahaan. Sebagai catatan, hak disini adalah hak seluruh stakeholders, bukan terbatas kepada shareholders saja. Hak adalah berbagai kekuatan yang dimiliki stakeholders secara individual untuk mempengaruhi manajemen. Proses, maksudnya adalah mekanisme dari hak-hak tersebut. Adapun pengendalian merupakan mekanisme yang memungkinkan stakeholders menerima informasi yang diperlukan seputar aneka kegiatan perusahaan. (Mustikaningrum 2011)

3. Forum for Corporate Governance in Indonesia (FCGI) (2001:2): GCG didefinisikan sebagai "Seperangkat peraturan yang mengatur hubungan antara pemegang, pengurus (pengelola) perusahaan, pihak kreditur, pemerintah, karyawan, serta para pemegang kepentingan internal dan eksternal lainnya yang berkaitan dengan hak-hak dan kewajiban mereka atau dengan 
kata lain suatu system yang mengendalikan perusahaan. Tujuan corporate governance ialah untuk menciptakan nilai tambah bagi semua pihak yang berkepentingan (stakeholders)" Noviatani dan Fatimmah 2016).

4. Finance Comitte on Corporate Governance Malaysia: $\quad \mathrm{GCG}$ merupakan suatu proses serta struktur yang digunakan untuk mengarahkan sekaligus mengelola bisnis dan urusan perusahaan kearah peningkatan pertumbuhan bisnis dan akuntabilitas perusahaan. Adapun tujuan akhirnya adalah menaikkan nilai saham dalam jangka panjang tetapi tetap memerhatikan berbagai kepentingan para stakeholder lainnya (Pertiwi 2015).

5. Peraturan Lembaga zakat Indonesia: GCG adalah suatu tata kelola Lembaga zakat yang menerapkan prinsip-prinsip transparansi (transparency), akuntabilitas (accountability), pertanggungjawaban (responsibility), independensi (independency), dan kewajaran (fairness).

Berdasarkan berbagai uraian mengenai GCG diatas maka Good Corporate Governance merupakan pedoman system, aturan main serta komitmen bagaimana melaksanakan tata kelola perusahaan atau lembaga dengan baik, beretika, untuk meningkatkan kinerja lembaga dan melindungi stakeholder/shareholder. Brown and Caylor (2004) menjelaskan bahwa pelaksanaan GCG yang efektif dan efisien, akan menjadikan seluruh proses aktivitas perusahaan akan berjalan dengan baik, sehingga hal-hal yang berkaitan dengan kinerja perusahaan baik yang sifatnya kinerja finansial maupun non finansial akan juga turut membaik.

Terdapat empat komponen utama yang diperlukan dalam GCG, (Kaen, 2003; Shaw, 2003) yaitu (1) fairness, (2) transparency, (3) accountability, dan (4) responsibility. Keempat komponen tersebut penting karena penerapan prinsip GCG secara konsisten terbukti dapat meningkatkan kualitas laporan keuangan dan juga dapat menjadi penghambat aktivitas rekayasa kinerja yang mengakibatkan laporan keuangan tidak menggambarkan nilai fundamental 
perusahaan.

C. GCG di Indonesia

Kajian yang dilakukan oleh Asian Development Bank (ADB) menunjukkan beberapa faktor yang memberi kontribusi pada krisis di Indonesia. Pertama, konsentrasi kepemilikan perusahaan yang tinggi. Kedua, tidak efektifnya fungsi pengawasan dewan komisaris. Ketiga, inefisiensi dan rendahnya transparansi mengenai prosedur pengendalian merger dan akuisisi perusahaan. Keempat, terlalu tingginya ketergantungan pada pendanaan eksternal dan kelima, ketidakmemadaiannya pengawasan oleh para kreditor.Tantangan terkini yang dihadapi masih belum dipahaminya secara luas prinsip-prinsip dan praktek GCG oleh komunitas bisnis dan publik pada umumnya (Kaihatu, 2006). Komunitas internasional masih menempatkan Indonesia pada urutan bawah rating implementasi GCG sebagaimana dilakukan oleh Standard \& Poor, CLSA, Pricewaterhouse Coopers, Moody`s Morgan, and Calper`s.

Dalam penerapan $G C G$ di Indonesia, seluruh pemangku kepentingan turut berpartisipasi. Komite Nasional Kebijakan
Governance telah menerbitkan Pedoman tersebut kemudian disusul dengan penerbitan Pedoman GCG perbankan Indonesia, pedoman untuk komite audit, dan pedoman untuk komisaris independen di tahun 2004. Semua pedoman ini dipandang perlu untuk memberikan acuan dalam mengimplementasikan GCG. Menurut Ketua Komite Nasional Kebijakan Governance, Penerapan GCG dapat didorong dari dua sisi, yaitu etika dan peraturan. Dorongan dari etika (ethical driven) datang dari kesadaran individuindividu pelaku bisnis untuk menjalankan praktik bisnis yang mengutaman kelangsungan hidup perusahaan dan kepentingan stakeholders. Dorongan dari peraturan (regulatory driven) mengharuskan perusahaan untuk patuh terhadap peraturan perundang-undangan yang berlaku. Kedua pendekatan ini memiliki kekuatan dan kelemahannya masing-masing namun diharapkan saling melengkapi untuk menciptakan lingkungan bisnis yang sehat.

D. Implementasi GCG pada NGO Setiap lembaga baik perusahaan maupun NGO harus memastikan bahwa asas dan prinsip dasar GCG diterapkan dalam 
setiap aspek bisnis maupun organisasi.

Secara umum terdapat lima prinsip dasar dari GCG yaitu (Kaihatu, 2006):

(1) Transparency (keterbukaan informasi), yaitu keterbukaan dalam melaksanakan proses pengambilan keputusan dan keterbukaan dalam mengemukakan informasi materiil dan relevan mengenai perusahaan. NGO harus menyediakan informasi yang relevan dengan cara yang mudah diakses dan dipahami oleh pemangku kepentingan untuk menjaga objektivitas dalam menjalankan kegiatannya. NGO harus menjelaskan secara terbuka sumber dana didapatkan dan untuk apa dana donatur dipergunakan sehingga keterbukaan informasi ini membuat donatur mengetahui kemana dana yang mereka sedekahkan diberikan.

(2) Accountability (akuntabilitas), yaitu kejelasan fungsi, struktur, sistem, dan pertanggungjawaban organ perusahaan sehingga pengelolaan perusahaan terlaksana secara efektif. Perusahaan harus dapat mempertanggungjawabkan kinerjanya secara transparan, akuntabel dan wajar. Untuk itu NGO harus dikelola secara benar, terukur dan sesuai dengan program kerja yang sudah dirancang. Akuntabilitas merupakan prasyarat yang dipelrukan untuk mencapai kinerja yang berkesinambungan.

(3) Responsibility (pertanggungjawaban), yaitu kesesuaian (kepatuhan) di dalam pengelolaan perusahaan terhadap prinsip korporasi yang sehat serta peraturan perundangan yang berlaku. NGO harus mematuhi peraturan perundang-undangan serta melaksanakan tanggung jawab terhadap masyarakat dan lingkungan sehingga dapat terpelihara keberlangsungan NGO dalam jangka panjang dan mendapat pengakuan sebagai Good Corporate Citizen.

(4) Independency (kemandirian), yaitu suatu keadaan dimana perusahaan dikelola secara profesional tanpa benturan kepentingan dan pengaruh/tekanan dari pihak manajemen yang tidak sesuai dengan peraturan dan perundangan-undangan yang berlaku dan prinsip-prinsip korporasi yang sehat. 
Untuk melaksanakan prinsip dasar GCG,

NGO harus dikelola secara independen dan menghindari intervensi atau ditumpangi kepentingan dari pihak lain.

(5) Fairness (kesetaraan dan kewajaran), yaitu perlakuan yang adil dan setara di dalam memenuhi hak-hak stakeholder yang timbul berdasarkan perjanjian serta peraturan perundangan yang berlaku.

Esensi dari corporate governance adalah peningkatan kinerja perusahaan melalui supervisi atau pemantauan kinerja manajemen dan adanya akuntabilitas manajemen terhadap pemangku kepentingan lainnya, berdasarkan kerangka aturan dan peraturan yang berlaku. Diharapkan dengan menerapkan prinsip ini NGO bisa meningkatkan citranya dimata para shareholder/stakeholder. Mekanisme check and balance dapat dijamin dengan penerapan prinsip GCG terutama untuk melindungi kepentingan setiap stakeholder yang terlibat dalam aktivitas NGO. Transparansi dan akuntabilitas merupakan prinsip yang dijadikan acuan dalam penyusunan regulasi untuk menghindari terjadinya konflik kepentingan terutama dalam hal praktik manajemen resiko dalam pelaporan keuangan (Kaihatu, 2006). Oleh karenanya, berdasarkan kelima prinsip dasar GCG diatas, akuntabilitas serta transparansi memegang peranan yang sangant penting dalam pelayanan publik sebuah NGO. Berdasarkan penerapan prinsip tersebut dapat dilihat seberapa jauh penyelenggaraan pelayanan NGO memiliki kesesuaian dengan nilai-nilai atau norma-norma masyarakat atau stakeholder. Sementara akuntabilitas NGO adalah suatu proses pertanggung jawaban secara terbuka mengenai apa yang diyakini, apa yang dilakukan dan tidak dilakukan. Secara operasional, akuntabilitas diwujudkan dalam bentuk pelaporan (reporting), pelibatan (involuing), dan cepat tanggap (responding). Sejalan yang disampaikan oleh Edwards dan Hulme (1998) yang menyatakan bahwa akuntabilitas NGO yang efektif serta transparasi secara eksplisit memiliki ciriciri:

(1) NGO mendefinisikan tujuan yang jelas mengenai peran serta kontribusinya di masyarakat. Karena untuk menunjukkan akuntabilitasnya, shareholders perlu mengetahui secara jelas kesesuaian antara kinerja NGO dalam 
bentuk kesesuaian antara permasalahan dan solusi yang diberikan kepada masyarakat.

(2) NGO melakukan keterbukaan terhadap publik mengenai laporan mengenai asal, alokasi dan pengunaan resources secara jujur. Dengan begitu shareholders bisa mendapatkan informasi yang jelas dan akurat mengenai dana masuk dan keluar yang dipergunakan $N G O$ untuk membiaya program kerjanya.

Berdasarkan standar dasar akuntabilitas

LSM (Konsil LSM Indonesia, 2004), akuntabilitas bagi LSM adalah kewajiban LSM untuk menjelaskan dasar pembenaran tindakan organisasi (termasuk oleh stafnya) kepada orang di luar organisasi. Disamping itu LSM juga perlu memberikan kesempatan kepada orang luar untuk memutuskan pembenaran atas tindakan tersebut, dan bertanggung jawab atas pertanyaan dari orang luar organisasi, serta memberi respon atas saran yang diberikan kepada organisasi. Akuntabilitas LSM juga dipahami sebagai kewajiban LSM untuk menjelaskan dasar pembenaran (sesuai prinsip dan aturan dianut) sikap, prilaku dan keputusan- keputusan yang diambilnya serta memberi kesempatan kepada publik menilai dan menyampaikan keluhan. Supaya akuntabilitas bisa dilakukan oleh orang di luar organisasi secara efektif, LSM sendiri harus melakukan praktek akuntabilitas di dalam organisasi.

Penerapan prinsip akuntabilitas dalam NGO menjadi penting karena, NGO adalah lembaga yang bekerja untuk masyarakat dan berdasarkan pada kepercayaan. Untuk meningkatkan serta menjamin tingkap kepercayaan para stakeholder/shareholder diperlukan standar dan panduan agar dapat terukur. NGO dengan akuntabilitas yang kuat diharapkan dapat menghindari potensi tindak korupsi, penyelewengan maupun praktek negatif lainnya. Dengan demikian, pengembangan akuntabilitas NGO diharapkan dapat meningkatkan efektifitas pelayanan yang dilakukan NGO kepada masyarakat penerima manfaat maupun keterbukaan kepada penyandang dana.

Lahirnya dokumen kode etik LSM tahun 1994 di Indonesia, menjadi bukti perhatian dan respon komunitas NGO terhadap isu akuntabilitas yang ditandai dalam sebuah pertemuan yang 
diselenggarakan oleh Bina Desa di Bogor.

Namun, konsensus yang telah dibangun terhadap kode etik ini relatif belum berdampak. Diskursus tentang akuntabilitas NGO pasca tahun 1998, kembali diperhatikan untuk merespon berdirinya ribuan organisasi baru yang menyebut dirinya LSM dengan macam-ragam motif dan karakter yang sebagiannya bertentangan dengan misi dan prinsip- prinsip layaknya sebuah LSM. Kecenderungan baru ini telah berdampak serius terhadap reputasi komunitas $N G O$ Indonesia, meski hanya sebagian organisasi yang berperilaku negatif namun memberikan dampak serius pada LSM lainnya.

Inisiasi jaringan LSM untuk Kode Etik diinisiasi oleh LP3ES di beberapa provinsi di Indonesia pasca tahun 1998. Selanjutnya sejumlah aktivis dan organisasi yang terlibat dalam inisiatif tersebut membentuk kelompok kerja untuk akuntabilitas ormas. Kemudian bersama 94 LSM di 14 provinsi sejumlah aktivis LSM melahirkan Konsil LSM Indonesia dengan salah satu misi utama yaitu memperluas kesadaran dan meningkatkan kemampuan serta praktek akuntabilitas komunitas LSM Indonesia.
E. Implementasi Akuntabilitas di Migrant Institute

Implementasi akuntabilitas di kalangan organisasi nirlaba di Indonesia saat ini relatif kurang. Disamping itu, saat ini belum banyak organisasi nirlaba yang berupaya untuk meningkatkan prosedur operasional (baik SOP maupun AD/ART) yang mengatur organisasi mereka. Salah satu penyebabnya adalah terdapat resistensi atau keengganan, terutama bagi organisasi yang menerima bantuan dana asing. Resistensi tersebut ditunjukan dengan keengganan untuk melakukan proses pengambilan keputusan internal dan membuat situasi keuangan mereka transparan serta mempertanggungjawabkannya kepada publik. Sebagai bagian dari penerapan prinsip akuntabilitas hal tersebut justru menjadi penting dilakukan oleh NGO karena NGO bertanggung jawab atas semua nilai-nilai yang dianutnya, apa yang dilakukan atau tidak dilakukannya, kepada semua stakeholder (kelompok sasaran, lembaga donor, sesama NGO, pemerintah dan masyarakat luas).

Migrant Institute dibentuk oleh Dompet Dhuafa, sebuah NGO yang 
bergerak pada bidang sosial kemanusiaan, dengan latar belakang kepedulian kepada nasib buruh migran Indonesia pada tahun 1999. Sebelumnya, pada tahun 2003 Dompet Dhuafa membuat sebuah divisi program dengan nama Sahabat Pekerja Migran yang berfokus pada kegiatan dakwah, pendidikan, advokasi dan pemberdayaan. Secara struktural Migrant Institute merupakan bagian dari yayasan Dompet Dhuafa sehingga secara pendanaan, Migrant Institutesangat bergantung kepada Dompet Dhuafa.

Begitu pula dengan hal pengambilan kebijakan serta pelaporan, Dompet Dhuafa merupakan stakeholder utama. Gambaran implementasi prinsip akuntabilitas di Migrant Institute diantaranya yaitu:
1. Direktur eksekutif Dompet Dhuafa setiap satu tahun sekali, mengumpulkan seluruh staf serta para perwakilan presidium nasional KAMI (Keluarga Migran Indonesia) untuk melakukan pertemuan rutin persiapan Kongres Nasional. Dan di dalam forum tersebut, para staf maupun perwakilan presidium menanyakan pertanyaan mengenai kegiatan tersebut.

2. Migrant Institute melaporkan kegiatannya di akun media sosial dan memberikan kesempatan kepada publik untuk mengajukan pengaduan tentang staf dan organisasinya. Secara lengkap implementasi akuntabilitas Migrant Institute ditunjukan pada Tabel 1.

Tabel 1.

Implementasi Akuntabilitas Migrant Instituteberdasarkan standar Konsil LSM Indonesia

\begin{tabular}{|c|c|c|c|}
\hline No & Standar & $\begin{array}{c}\text { Implemen- } \\
\text { tasi }\end{array}$ & Bukti Verifikasi \\
\hline 1 & $\begin{array}{l}\text { Anggota Board yang berasal dari aparatur sipil } \\
\text { negara (ASN) lainnya tidak melebihi } 30 \text { persen. }\end{array}$ & V & $\begin{array}{ll}\text { - } & \text { Data diri } \\
\text { pengurus } \\
\text { - }\end{array}$ \\
\hline 2 & $\begin{array}{l}\text { Direktur Eksekutif dan anggota Eksekutif } \\
\text { lainnya yang bekerja sebagai pegawai tetap atau } \\
\text { yang menerima gaji/imbalan secara teratur tidak } \\
\text { merangkap sebagai ASN }\end{array}$ & V & - \\
\hline
\end{tabular}




\begin{tabular}{|c|c|c|c|}
\hline 3 & $\begin{array}{l}\text { Board dan Eksekutif } N G O \text { tidak boleh } \\
\text { merangkap menjadi pengurus partai politik }\end{array}$ & $\mathrm{V}$ & 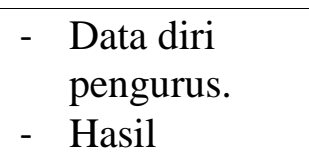 \\
\hline 4 & $\begin{array}{l}\text { Direktur Eksekutif dan anggota Eksekutif } \\
\text { lainnya yang bekerja sebagai pegawai tetap atau } \\
\text { yang menerima gaji/imbalan secara teratur tidak } \\
\text { merangkap sebagai aparatur sipil negara. }\end{array}$ & $\mathrm{V}$ & - \\
\hline 5 & $\begin{array}{l}\text { Board dan Eksekutif LSM tidak boleh } \\
\text { merangkap menjadi pengurus partai politik }\end{array}$ & $\mathrm{V}$ & $\begin{array}{ll}\text { - } & \text { Hasil } \\
& \text { wawancara. } \\
\text { - } & \text { Data diri } \\
& \text { pengurus }\end{array}$ \\
\hline 6 & $\begin{array}{l}\text { Board dan Eksekutif LSM tidak boleh } \\
\text { merangkap jabatan-jabatan politik (Pimpinan } \\
\text { nasional dan daerah, dan anggota legislatif dari } \\
\text { pusat sampai kabupaten) }\end{array}$ & $\mathrm{V}$ & $\begin{array}{ll}\text { - } & \text { Data diri } \\
& \text { pengurus } \\
\text { - } & \text { Hasil } \\
& \text { wawancara }\end{array}$ \\
\hline 7 & $\begin{array}{l}\text { Anggota Board atau Eksekutif yang ingin } \\
\text { mencalonkan diri untuk jabatan politik harus } \\
\text { mengundurkan diri terlebih dahulu sekurang- } \\
\text { kurang } 3 \text { (tiga) bulan sebelum pencalonan } \\
\text { diajukan. }\end{array}$ & $\mathrm{V}$ & $\begin{array}{l}\text { - Surat } \\
\text { pengunduran } \\
\text { diri/non aktif } \\
\text { yang } \\
\text { bersangkutan } \\
\text { yang } \\
\text { dipublikasikan } \\
\text { ke pemangku } \\
\text { kepentingan. }\end{array}$ \\
\hline 8 & $\begin{array}{l}\text { Direktur Eksekutif dan anggota Eksekutif } \\
\text { lainnya yang bekerja sebagai pegawai tetap } \\
\text { atau yang menerima gaji/imbalan secara } \\
\text { teratur tidak merangkap sebagai aparatur } \\
\text { sipil negara. }\end{array}$ & $\mathrm{V}$ & $\begin{array}{l}\text { - Laporan } \\
\text { keuangan }\end{array}$ \\
\hline 9 & $\begin{array}{l}\text { Board dan Eksekutif LSM tidak boleh } \\
\text { merangkap menjadi pengurus partai politik }\end{array}$ & $\mathrm{V}$ & - \\
\hline 10 & $\begin{array}{l}\text { Board Relawan NGO dalam menjalankan } \\
\text { fungsinya tidak berhak menerima gaji, } \\
\text { honorarium atau imbalan lain yang diberikan } \\
\text { secara rutin. }\end{array}$ & $\mathrm{V}$ & $\begin{array}{l}\text { - Laporan } \\
\text { keuangan }\end{array}$ \\
\hline 11 & $\begin{array}{l}\text { Board Relawan NGO yang memiliki } \\
\text { keahlian tertentu dan dibutuhkan oleh NGO } \\
\text { dapat diberikan honorarium untuk } \\
\text { kontribusinya berdasarkan kesepakatan } \\
\text { tertulis. }\end{array}$ & - & $\begin{array}{ll}\text { - } & \text { Kontrak kerja. } \\
\text { - } & \text { Lapoan } \\
& \text { keuangan. } \\
\text { - } & \text { Hasil } \\
& \text { kegiatan } \\
& \text { (output). }\end{array}$ \\
\hline
\end{tabular}




\begin{tabular}{|c|c|c|c|}
\hline 12 & $\begin{array}{l}\text { LSM memiliki kebijakan tentang } \\
\text { representasi dan partisipasi perempuan } \\
\text { secara bermakna dalam jabatan Board dan } \\
\text { Top eksekutif }\end{array}$ & - & $\begin{array}{ll}\text { - } & \text { AD/ART } \\
\text { - } & \text { Struktur } \\
& \text { organisasi }\end{array}$ \\
\hline 13 & $\begin{array}{l}\text { Organisasi memiliki aturan dasar organisasi } \\
\text { (AD/ART atau dokumen aturan lain yang } \\
\text { setara) yang meliputi sekurang-kurangnya: a) } \\
\text { Visi misi organisasi b) Program/strategi } \\
\text { utama } \\
\text { c) Mekanisme Pengambilan keputusan tertinggi } \\
\text { d) Rapat rapat pengambil keputusan organisasi } \\
\text { e) Periodesasi untuk jabatan Board dan direktur } \\
\text { eksekutif f) Tugas \& tanggung jawab (Board \& } \\
\text { Direktur Eksekutif) g) Pembagian Kewenangan } \\
\text { (struktur organisasi). h) Hak dan kewajiban } \\
\text { anggota (tidak berlaku untuk yayasan) i) } \\
\text { Sumber perdanaan (etika penggalangan dana) }\end{array}$ & $\mathrm{V}$ & $\begin{array}{l}\text { - Dokumen } \\
\text { AD/ART hasil } \\
\text { Pertemuan } \\
\text { Tertinggi } \\
\text { Organsiasi. }\end{array}$ \\
\hline 14 & $\begin{array}{l}\text { Struktur organisasi terdiri dari sekurang- } \\
\text { kurangnya } 2 \text { unsur, yaitu Board dan Eksektif; } \\
\text { dan personil unsur-unsur tersebut harus } \\
\text { dipisahkan. }\end{array}$ & $\mathrm{V}$ & 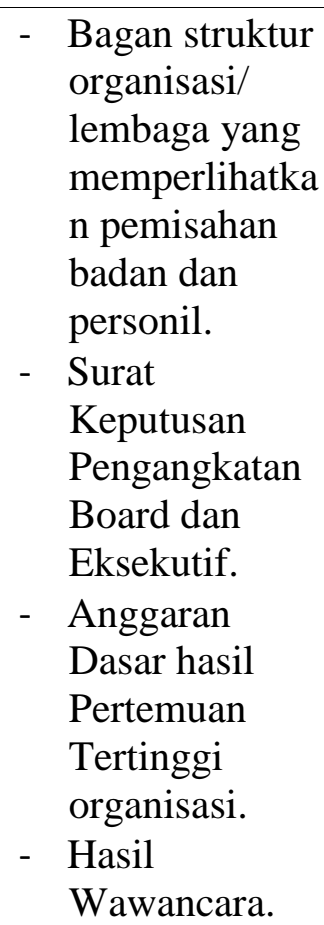 \\
\hline 15 & $\begin{array}{l}\text { Organisasi melaksanakan musyawarah } \\
\text { besar/kongres/ pertemuan setara sebagai } \\
\text { forum pengambilan keputusan tertinggi yang } \\
\text { dihadiri oleh semua unsur organisasi yaitu } \\
\text { board, eksekutif, relawan, } 27 \text { anggota } \\
\text { (kecuali yayasan), perwakilan masyarakat } \\
\text { dampingan/mitra maksimum sekali dalam } 5 \\
\text { tahun. }\end{array}$ & $\mathrm{V}$ & $\begin{array}{l}\text { - Daftar hadir } \\
\text { kongres/mubes } \\
\text { / pertemuan } \\
\text { setara lainnya } \\
\text { - Notulen } \\
\text { kongres/mubes } \\
\text { / pertemuan } \\
\text { setara lainnya. } \\
\text { - Wawancara } \\
\text { dengan Board } \\
\text { \& Eksekutif }\end{array}$ \\
\hline
\end{tabular}




\begin{tabular}{|c|c|c|c|}
\hline 16 & $\begin{array}{l}\text { Organisasi memiliki ketentuan tentang } \\
\text { periodesasi jabatan Board dan eksekutif } \\
\text { paling lama } 5 \text { tahun dan maksimal } 2 \text { kali } \\
\text { masa jabatan. }\end{array}$ & $\mathrm{V}$ & $\begin{array}{ll}\text { - Anggaran } \\
\text { Dasar/ART } \\
\text { minimum hasil } \\
\text { pertemuan } \\
\text { tertinggi } \\
\text { organisasi. }\end{array}$ \\
\hline 17 & $\begin{array}{l}\text { Organisasimelakukan pengambilan } \\
\text { keputusan terkait hal-hal berikut dalam } \\
\text { musyawarah besar/kongres/ pertemuan } \\
\text { setara. a) Pengesahan AD/ART b) Pemilihan } \\
\text { board didasarkan periodesasi jabatan Badan } \\
\text { Pengurus yang disahkan AD/ART c) } \\
\text { Perumusan program strategis d) Penerimaan } \\
\text { atau penolakan laporan pertanggungjawaban } \\
\text { program dan keuangan oleh board. }\end{array}$ & $\mathrm{V}$ & $\begin{array}{l}\text { Notulen } \\
\text { kongres/mu } \\
\text { bes/pertemu } \\
\text { an setara } \\
\text { lainnya. } \\
\text { - Wawancara } \\
\text { dengan } \\
\text { Board \& } \\
\text { Eksekutif. }\end{array}$ \\
\hline 18 & $\begin{array}{l}\text { Organisasi melakukan rapat berkala board } \\
\text { sekurangkurangnya sekali dalam setahun. }\end{array}$ & $\mathrm{V}$ & $\begin{array}{ll}\text { - } & \text { Surat } \\
\text { Keputusan/Beri } \\
\text { ta } \\
\text { - } \text { Acara } \\
\text { Pengangkatan } \\
\text { Board } \\
\text { - } & \text { Notulen rapat } \\
\text { Board } \\
\text { - Wawancara } \\
\text { dengan Board } \\
\text { \& Eksekutif }\end{array}$ \\
\hline 19 & $\begin{array}{l}\text { Organisasi harus memastikan tanggung } \\
\text { jawab Board dan Eksekutif yang } \\
\text { sekurangkurangnya meliputi: a) Board } \\
\text { mengangkat dan memberhentikan Direktur } \\
\text { eksekutif. b) Board memilih Direktur } \\
\text { eksekutif berdasarkan periodesasi Direktur } \\
\text { eksekutif yang disahkan di AD/ART. c) } \\
\text { Board mengesahkan kegiatan dan anggaran } \\
\text { tahunan yang disusun oleh Direktur } \\
\text { eksekutif. d) Board menerima } \\
\text { pertanggungjawaban pelaksanaan program } \\
\text { dan penggunaan anggaran dari Direktur } \\
\text { eksekutif setiap tahun. e) Pengambilan } \\
\text { keputusan oleh Direktur eksekutif } \\
\text { dikomunikasikan kepada board seperti } \\
\text { penetapan standar gaji, membangun dan/atau } \\
\text { mengakhiri kerja sama dengan pihak lain, } \\
\text { dan menyusun dan/atau mengubah SOP. }\end{array}$ & $\mathrm{V}$ & $\begin{array}{l}\text { - Wawancara } \\
\text { dengan Board } \\
\text { \& staff }\end{array}$ \\
\hline
\end{tabular}




\begin{tabular}{|l|l|c|l|}
\hline 20 & $\begin{array}{l}\text { Direktur eksekutif melaksanakan rapat staf } \\
\text { sekurang-kurangnya satu bulan sekali secara } \\
\text { partisipatif untuk menyusun perencanaan } \\
\text { kegiatan dan evaluasi kegiatan bulanan. }\end{array}$ & $\mathrm{V}$ & $\begin{array}{l}\text { - Notulen rapat } \\
\text { - Rencana } \\
\text { kerja } \\
\text { bulanan }\end{array}$ \\
\hline 21 & $\begin{array}{l}\text { Staf terlibat dalam pembuatan kebijakan } \\
\text { strategis lembaga yang ditetapkan oleh } \\
\text { Board dan Direktur eksekutif minimum yaitu } \\
\text { dalam hal: a. Penyusunan dan pembahasan } \\
\text { gaji. b. Memulai atau mengakhiri kerja sama } \\
\text { dengan pihak lain. c. Pembahasan dan } \\
\text { peninjauan SOP. }\end{array}$ & $\mathrm{V}$ & $\begin{array}{l}\text { Wawancara } \\
\text { dengan staf. }\end{array}$ \\
\hline
\end{tabular}

Berdasarkan hasil identifikasi dan kajian faktor-faktor penentu dalam standar implementasi akuntabilitas NGO Migrant Instituteperlu mengambil tindakan-tindakan perbaikan diantaranya:

(1) Migrant Institute perlu melakukan pembenahan administrasi (internal) mengacu pada standar dasar akuntabilitas NGO yang terbitkan oleh Konsil LSM. Standar ini tidaklah mutlak namun bisa dijadikan acuan dalam mengimplementasikan Good Corporate Governance melalui Akuntabilitas yang efektif serta transparasi.

(2) Perlunya melengkapi instrumen transparansi pelaporan kepada publik seperti website yang keberadaannya sangat krusial. Migrant Institute bisa melaporkan berbagai kegiatan maupun program yang sudah dilakukan, yang tengah dilakukan, maupun yang akan dilakukan sehingga para stakeholders mengetahui apa saja yang dilakukan Migrant Institute.

(3) Migrant Institute perlu mendokumentasikan berbagai kegiatan maupun programnya dengan baik seperti membuat database penerima manfaat sehingga akan memudahkan dalam melakukan proses koordinasi, monitoring dan evaluasi.

(4) Pembuatan SOP yang lebih jelas dan detil untuk penyelenggara program maupun proses kerja. Selama ini SOP yang terdokumentasikan dengan baik baru SOP bagian Keuangan.

(5) Mendorong lembaga untuk mandiri dari sisi pendanaan. Hal ini penting dalam hal penerapan prinsip GCG 
sehingga Migrant Institutebisa

bertranspormasi menjadi lembaga

mandiri dan independen.

(6) Memberikan porsi bagi perempuan didalam jabatan Board atau top eksekutif.

(7) Migrant Istitute perlu memiliki kebijakan tentang mekanisme penerimaan dan penanganan keluhan (complain handling mechanism) dari penerima manfaat dan pemangku kepentingan lainnya yang minimal meliputi (a) siapa akan bertanggung jawab atas penanganan keluhan, (b) bagaimana keluhan bisa disampaikan dan (c) tahap-tahap untuk penahanan keluhan.

(8) Perlu dilakukan kajian lain untuk mengetahui factor-faktor yang mempengaruhi tingginya angka resign staf media.

(9) Penerapan GCG pada sebuah lembaga tidak serta merta meningkatkan citra positif lembaga, Migrant Institute perlu melakukan langkah-langkah lanjutan seperti "branding" untuk mendongkrak citra positif lembaga serta lebih dikenal oleh masyarakat.

Mengoptimalkan pemanfaatan sosial media seperti facebook dan twitter dinilai cukup efektif dan sangat efesien dalam proses peningkatan reputasi lembaga.

\section{KESIMPULAN}

Berdasarkan hasil kajian yang dilakukan diketahui bahwa prinsip-prinsip dalam GCG diantaranya yang paling prioritas adalah prinsip transparansi dan akuntabilitas. Dalam hal membangun akuntabilitas serta transparansi, Migrant Institutesudah berupaya menerapkan prinsip-prinsip GCG pada lembaganya diantaranya yaitu terdapat SOP untuk bidang keuangan, adanya pelaporan kepada publik melalui media sosial seperti Facebook, Twitter, blog dan website. Namun, sayangnya pada saat observasi website Migrant Institute sedang berada dalam kondisi sulit diakses karena pengelolaan yang belum optimal, sehingga masyarakat tidak dapat lagi mengakses maupun melihat kegiatan serta program yang dilakukan.

Temuan ini mengkonfirmasi pendapat Mardiasmo (2011) bahwa 
Journal of Management Vol.14, No.1, January 2017: 233-257

akuntabilitas diartikan sebagai bentuk

kewajiban mempertanggungjawabkan

keberhasilan atau kegagalan pelaksanaan

visi misi organisasi yang telah ditetapkan

sebelumnya, melalui suatu media pertanggungjawaban yang dilaksanakan secara periodic. Migrant Institute juga telah melaksanakan prinsip akuntabilitas dalam GCG, yang diatur oleh National Committee on Governance dalam Sukrisno ( 2014 ). Akuntabilitas sebagai prinsip bagi para pengelola berkewajiban untuk membina system akuntansi yang efektif untuk menghasilkan laporan keuangan yang dapat dipercaya, sehingga diperlukan kejelasan fungsi, $\quad$ pelaksanaan, dan pertanggungjawaban setiap organ perusahaan ( organisasi )

Hasil penelitian pelaksanaan akuntabilitas pada Migrant Institute ini tidak sama dengan penelitian yang dilakukan Hafidh (2008) menyatakan bahwa standar terkait pelaksanaan akuntabilitas bagi LSM belum cukup memadai dalam upaya pengungkapanya. Hasil penenlitian ini mengkonfirmasi keseuaian hasil penelitian yang dilakukan oleh Putri (2013) Implementasi akuntabilitas dan transparansi yang telah diterapkan oleh rumah sakit Saiful Anwar Malang telah berjalan dengan baik serta penelitian Gozyali (2012) menyatakan bahwa laporan keuangan dan pengelolaan kinerja Indonesia Corruption Watch (ICW) dinilai akuntabel.

Beberapa kendala yang dihadapi oleh Migrant Institute dalam rangka menuju penyelenggaraan organisasi yang sesuai dengan prinsip Corporate Governance diantaranya seperti mindset para karyawan yang merasa belum siap untuk bekerja lebih sistematis dan rapi. Selain itu, mereka merasa beban kerjanya bertambah jika harus mengerjakan pekerjaan diluar yang biasa mereka lakukan, padahal penerapan GCG dalam lembaga dimaksudkan untuk lebih memudahkan dan melindungi hak berbagai pihak stakeholder maupun shareholder. 


\section{DAFTAR PUSTAKA}

Abidin H, Rukmini M., 2004. Kritik dan otokritik LSM: membongkar kejujuran keterbukaan lembaga swadaya masyarakat Indonesia. Jakarta (ID): Piramedia. Hal: 60-70

Agoes S \& Ardna J , 2014. Etika Bisnis dan Profesi , Tantangan Membangun Manusia Seutuhnya, Salemba Empat Jakarta.

Alex G., 2014. Analisis Penerapan Good Corporate Governance Pada PT. Surya Bangun Jaya Abadi (Terwaralaba Ray White). Agora. 2 (2):xx-xx.

Brooks LJ \& Dunn P 2012 Business \& Professional Ethics, Cengage Learning Asia Pte, Ltd.

Edwards M, Hulme D. 1998. Too Close For Comfort? The Impact of Official Aid on Nongovernmental Organizations. Current Issues in Comparative Education. 1(1): 1-21

Fikri A, Sudarma M, Sukoharsono EG, Purnomoshidi B, Triyuwono I. 2010. Studi Fenomenologi Akuntabilitas Non governmental organization. [Internet]. [Diunduh 24 Februari 2016 ]. Tersedia di : http://asp.trunojoyo.ac.id/wp-content/uploads/2014/03/ASP_16_Q.pdf

Gozyali, Muhammad. 2012. Akuntabilitas Dan Transparansi Dalam Pengelolaan Keuangan (Studi Kasus Pada Indonesia Corruption Watch). Skripsi. Yogyakarta: Program Studi Sarjana Akuntansi Universitas Islam Indonesia.

Hafild, Emmy. 2008. Standar Akuntansi Keuangan Khusus Partai Politik. Jakarta:Transparency International Indonesia.

Kaihatu, TS. 2006. Good Corporate Governance dan Penerapannya di Indonesia. Jurnal Manajemen dan Kewirausahaan. 8 (1): 1-9.

Konsil LSM Indonesia. 2014. Standar Dasar Akuntabilitas LSM: Panduan Bagi LSM Anggota.Jakarta (ID): Konsil LSM Indonesia.

Mardiasmo. 2011. Perwujudan Transparansi dan Akuntabilitas Publik Melalui Akuntansi Sektor Publik: Suatu Sarana Good Governance. Jurnal Akuntansi Pemerintah Vol. 2, No. 1, Mei 2011. 1-17.

Muhtar G. 2010. Kontribusi Organisasi Sosial dalam Pembangunan Kesejahteraan Sosial. Jakarta (ID: Kemensos RI.

Mustikaningrum MA. 2011. Pengaruh Penerapan Corporate Governance dan Kepemilikan Institusional Terhadap Nilai Pasar Perusahaan yang Terdaftar dalam Corporate Governance Perception Index. [Skripsi]. Yogyakarta (ID): Universitas Atma Jaya.

Novatiani RA, Fatimmah J. 2016. Pengaruh penerapan good corporate Governance Terhadap Keandalan Laporan Keuangan ( Suvei pada Tiga Perusahaan BUMN di Bidang Jasa di Bandung). [Internet].

Diunduh24Februari2016.Tersediadi:http://repository.widyatama.ac.id/xmlui/bitstream/handle/123456789/22 7/31.pdf sequence 1

Pertiwi IGAE. 2015. Penyelenggaraan Sistem Informasi Hukum Perusahaan pada Badan Usaha Bank Umum dalam Pelaksanaan Good Corporate Governance [tesis]. Denpasar (ID): Universitas Udayana.

Putri, Ira Ardella. 2013. Implementation of Accountability and Transparency in Public Service (Study Case at IRD RSUD Dr. Saiful Anwar). Skripsi. Malang: Program Studi Sarjana Akuntansi Universitas Brawijaya.

Suharko. 1998. Model-Model Gerakan NGO Lingkungan: Studi Kasus di Yogyakarta. Jurnal Sospol (JSP). 2 (1): 40-62.

Surya I, Yustiavandana, I. 2008. Penerapan Good Corporate Governance. Mengesampingkan Hak- Hak Istimewa demi Kelangsungan Usaha. Jakarta (ID): Kencana Prenada Media Group

Sutedi A, 2011 Good Corporate Governance, Sinar Grafika Jakarta.

Tuanakotta M.T 2016 Akuntansi Forensik \& Audit Investigatif, Salemba Empat.

http://regional.kompas.com/read/2011/09/06/18513319/DPR.Greenpeace.Lakukan.Kebohongan.Publik.

http://konsillsm.or.id/akuntabilitas-publik-dan-buruknya-citra-lsm/Akuntabilitas Publik dan Buruknya Citra LSM. 